\title{
Tandem suturing and disarticulation of the Taiwan orogen revealed by its neotectonic elements
}

\author{
J. Bruce H. Shyu, ${ }^{\mathrm{a}, *}$, Kerry Sieh ${ }^{\mathrm{a}}$, Yue-Gau Chen ${ }^{\mathrm{b}}$ \\ ${ }^{a}$ Division of Geological and Planetary Sciences, California Institute of Technology, MC 100-23, Pasadena, CA 91125, USA \\ ${ }^{\mathrm{b}}$ Department of Geosciences, National Taiwan University, Taipei, Taiwan
}

Received 22 September 2004; received in revised form 18 January 2005; accepted 19 January 2005

Available online 24 March 2005

Editor: R.D. van der Hilst

\begin{abstract}
Taiwan's numerous active faults and folds demarcate distinct eastern and western neotectonic belts. The western belt results from the attachment and subsequent detachment of a sliver of continental lithosphere to the Eurasian continental margin. The eastern belt is the product of the same continental sliver docking with and then separating from the Luzon volcanic arc. Thus, the active Taiwan orogen is a tandem suturing and tandem disengagement of a volcanic arc and a continental sliver to and from the Eurasian continental margin. This progressive suturing and separation is a superb, living demonstration of the fundamental weakness of lithospheric sutures. Furthermore, this neotectonic architecture provides the basis for understanding the Taiwan's seismic sources.
\end{abstract}

(C) 2005 Elsevier B.V. All rights reserved.

Keywords: Taiwan; suture; neotectonics; seismic hazard; orogeny

\section{Introduction}

Taiwan is a result of the collision of Eurasian and Philippine Sea plates (e.g., [1-4]). Rapid rates of horizontal and vertical deformation [5-7] and an abundance of seismic activity [8-11] amply demonstrate the current vigor of the orogeny.

\footnotetext{
* Corresponding author. Tel.: +1 626395 6177; fax: +1 626395 1740 .

E-mail address: jbhs@gps.caltech.edu (J.B.H. Shyu).
}

The 1999 Chi-Chi earthquake and its unanticipated effects on population and infrastructure focused much scientific and public attention on Taiwan and demonstrated the urgent need for a better understanding of the island's seismic sources (e.g., [12-17]). In particular, the spectacular rupture of the Chelungpu thrust inspired us to investigate the fault's neotectonic context.

Fortunately, coincident with the occurrence of the earthquake, a high quality, high-resolution digital elevation model (DEM) of the island was produced. The DEM and new bathymetric maps afforded us the 
opportunity to conduct a broad survey of the geomorphic manifestation of active folding and faulting on the island and in nearby offshore regions. That geomorphologic investigation, augmented by consideration of published structural, stratigraphic, geodetic and seismologic data, led to the production of a neotectonic map and cross-sections of the island [18].

Construction of the neotectonic map led, in turn, to the model of the Taiwan orogen that we present below. We discuss the details of the neotectonic architecture of the island in [18].

\section{Neotectonic belts and domains of Taiwan}

Fig. 1 depicts the major active structures of Taiwan. The map shows that belts of active structures flank the mountainous backbone of the island on both the west and the east. Along both the eastern and the western belts, characteristics of active deformation vary markedly. Deformation across the southern and northern quarters of the island and adjacent seafloor is, for example, much more diffuse than across the central half of the island.

In the south, large anticlinal ridges and thrust faults deform the seafloors south of Taitung and Kao-hsiung (Fig. 1). These are expressions of the deformation and consumption of oceanic crust on both sides of the island's southern peninsula. On the east side, oceanic crust of the forearc basin is clearly underthrusting beneath a major west-dipping thrust fault, which has long been known from both bathymetry and seismic profiles (e.g., [19-21]). On the west side, two major left-lateral oblique thrust faults bound the rapidly subsiding Pingtung Plain. Between Tainan and Kaohsiung are several active north-south trending folds and NE-SW striking right-lateral faults. These onland structures accommodate E-W shortening and southward extrusion (e.g., [22]). GPS geodesy across the two regions flanking the southern peninsula shows that each is shortening at about $40 \mathrm{~mm} / \mathrm{yr}$ and that the western of the two is also extruding southward [5].
North of Taitung and Tainan, active deformation is more localized. East of the Central Range, most deformation is confined to the narrow Longitudinal Valley and its flanks (Fig. 1). The active left-lateral oblique Longitudinal Valley fault crops out along the eastern flank of the entire valley and dips steeply beneath the Coastal Range. Portions of this fault produced moderate earthquakes in 1951, 1995, and 2003 ([23,24]; R.-J. Rau, unpublished data). Along the southern half of the valley, an active reverse fault is also present along the western side of the valley [18]. The Central Range is riding over the valley along this structure. GPS geodesy shows that the rate of closure of the southern half of the valley is about 40 $\mathrm{mm} / \mathrm{yr}$ [5]. Closure rates are much lower in the north, but left-lateral rates of translation are similar in the north and south.

Between Tainan and Taipei, along the western neotectonic belt, shallow marine rocks of the continental shelf are being thrust onto the outer shelf of the Taiwan Strait (e.g., $[25,26])$. This shortening has four distinct manifestations, which lead us [18] to divide it into the Chiayi, Taichung, Miaoli, and Hsinchu Domains (Fig. 1). Major blind thrust faults accommodate most of the shortening across the Chiayi and Miaoli Domains [26,27]. Several active folds are present in the hanging-wall blocks of these structures. In contrast, two major thrust faults dominate the Taichung Domain. Rupture of the eastern one, the Chelungpu fault, produced the 1999 Chi-Chi earthquake. Pre-1999 geodetic rates of strain across this domain were much smaller than rates to the south. A large earthquake in 1935 resulted from failure of a bending-moment backthrust within one of the synclines of the Miaoli Domain and a right-lateral accommodation structure between the Miaoli and Taichung Domains. Right-lateral accommodation structures on the edges of the Chiayi Domain produced large earthquakes in 1906 and 1946.

Active structures in the northern domains accommodate extension above the Ryukyu subduction zone (Fig. 1). The Taipei Basin is a half-graben, bounded

Fig. 1. Map of the active faults and anticlines of the Taiwan orogen. Principal active faults and anticlines appear in red, and a key inactive fault appears as black dashes. Distinct western and eastern neotectonic belts flank the mountainous backbone of the island. The western belt reflects the docking of the Central Range (a continental sliver) to the Eurasian continental shelf. The eastern belt is the locus of docking of the Luzon volcanic arc to the same continental sliver. Collision is incipient across both belts in the south. Both sutures are coming undone in the north. A: Pre-collisional rapid and distributed convergence; B: Collision and suturing; C: Post-collisional collapse and extension; P: Outcrops of pillow lava along the western suture. Adapted from [18]. 


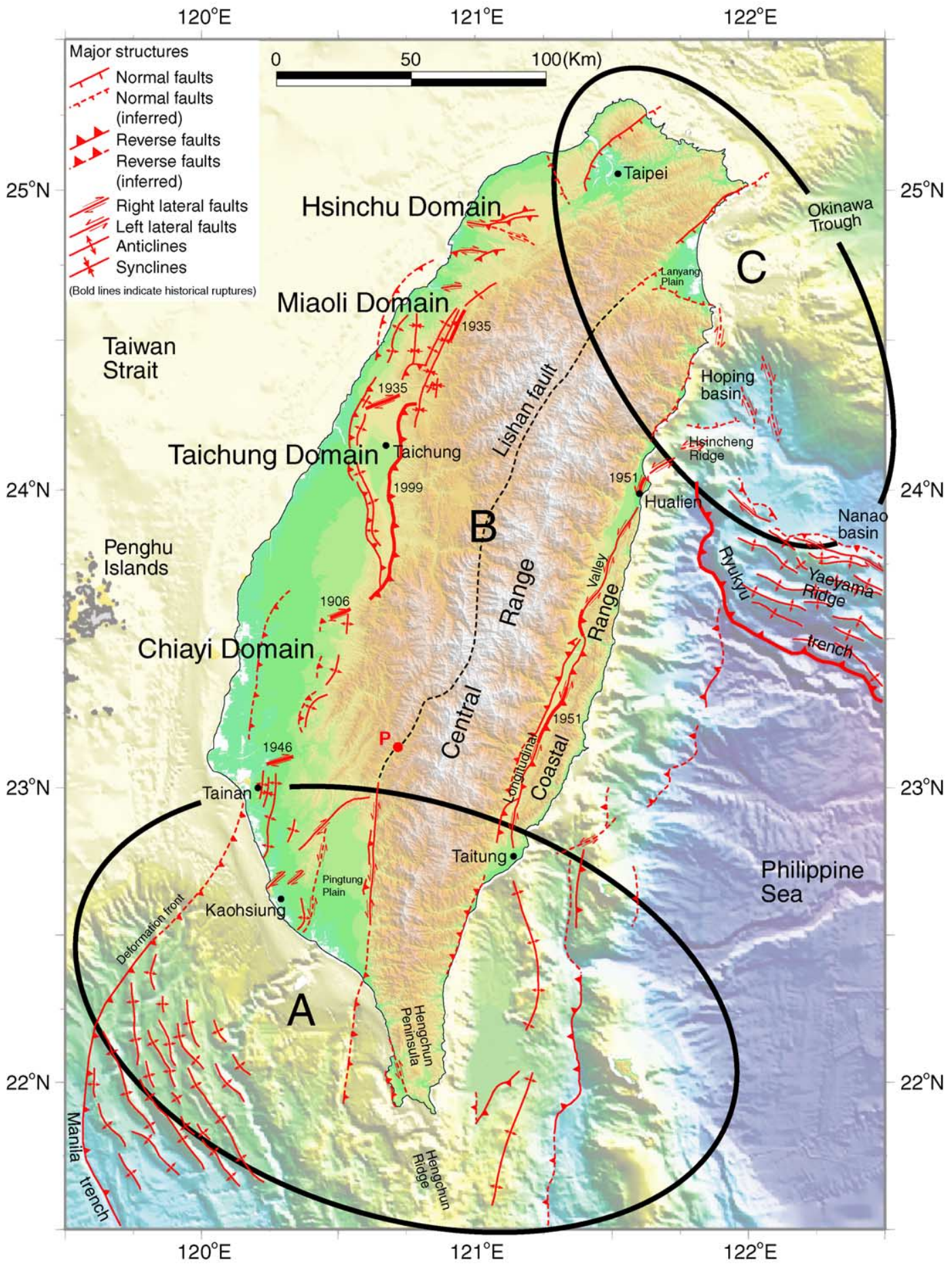


on the northwest by an active normal fault [28] that extends offshore as a minor fault on the continental shelf. This is consistent with GPS measurements, which show that the Taipei Basin is extending at low rates. Slip on this normal fault may have resulted in creation of a marine incursion into the basin in 1694 [29].

The Lanyang Plain is the westernmost, on-land extension of the Okinawa Trough (Fig. 1), which is opening as a back-arc basin at a rate of about 30-40 $\mathrm{mm} / \mathrm{yr}$ [30]. Active fault zones on both the northwestern and southern flanks of the plain are geomorphically evident, but others are buried beneath the rapidly aggrading valley floor and seafloor.

South of the Ryukyu island arc are two submarine basins and a fold and thrust belt associated with the deformation front of the Ryukyu subduction zone (Fig. 1). The Hoping basin is a triangular graben, bounded by normal faults on the west and south [18]. Bathymetry and historical seismicity indicate that right-lateral strike-slip faults traverse the basin. These help to accommodate the southward opening of the Okinawa Trough and the translation of the deformation front and Ryukyu island arc.

\section{The Taiwan orogen as accreting and disarticulating twin sutures}

Traditionally, the Taiwan orogen has been viewed by most as a classic example of active arc-continent collision, between the Luzon arc and the Eurasian continental margin (e.g., $[21,25,31,32]$ and references therein). In such views, the intervening Hengchun Ridge is simply the accretionary wedge at the leading edge of the Manila trench (Fig. 2).

However, the lack of a structural break between the Hengchun Ridge, Hengchun Peninsula, and the Central Range, and the presence of pre-Cenozoic continental basement in the Central Range of Taiwan (e.g., [33]) suggest that this strip may not be just a simple accretionary prism. This observation has inspired many alternative models for the Taiwan orogen (e.g., [34-37]). The pre-Cenozoic continental basement rocks in the Central Range led Lu and Hsü [38] to suggest that the Central Range is a continental block, rifted away from southeastern China. Based on the structural continuity of the Central Range and the
Hengchun Ridge, we think that they are, in fact, part of a thin sliver of continental lithosphere.

Moreover, this continental sliver may extend further to the east, as the basement of the westernmost part of the Ryukyu island arc. Except for a rightlateral tear, there appears to be no major structural break between the Central Range and the westernmost part of the arc (Figs. 1 and 2). Supporting this idea is the fact that at the latitude of the Ryukyu arc the structural grain of the Central Range bends distinctly eastward, toward the arc $[39,40]$. Thus it is plausible that the submarine Hengchun Ridge, the Central Range, and the substrate of the westernmost Ryukyu arc form a single, narrow but contiguous sliver of continental lithosphere, as suggested in Fig. 2.

This hypothesis and the active structures of Taiwan lead us to propose that the Taiwan orogen is a twin suturing and parting of three lithospheric blocks. The Luzon volcanic arc and the Hengchun Ridge/Central Range/westernmost Ryukyu continental sliver join and separate along the eastern neotectonic belt. The western neotectonic belt results from the suturing and separation of this same continental sliver and the Eurasian continental margin (Figs. 2 and 3).

Key to our tandem-suturing hypothesis is the claim that the Hengchun Ridge, Central Range and substrate of the westernmost Ryukyu island arc are the same buoyant lithospheric fragment. Many more observations than those mentioned above support this interpretation. The Hengchun Peninsula-an anticlinorial welt of deep marine rocks [41-43] that is rising at a rate of several $\mathrm{mm} / \mathrm{yr}[44,45]$-extends southward toward the Philippines as the elongate submarine Hengchun Ridge. Though covered by deep-marine rocks, distinctive gravity signals and P-wave velocity suggest that the underlying rocks of the ridge may have continental affinity (e.g., [46,47]). The Hengchun anticlinorium continues to the north as the Central Range, Taiwan's mountainous backbone, where exhumation has been great enough to expose Paleozoic granites, marbles, and schists of the continental sliver (e.g., [33]). Similar continental basement rocks may also exist beneath the marine rocks of the Hengchun anticlinorium, where the exhumation is just beginning. In the Central Range, the continental rocks are flanked by highly tectonized Cenozoic slates (e.g., [33]), which are likely the metamorphosed equivalent of the marine sedimentary cover of the 


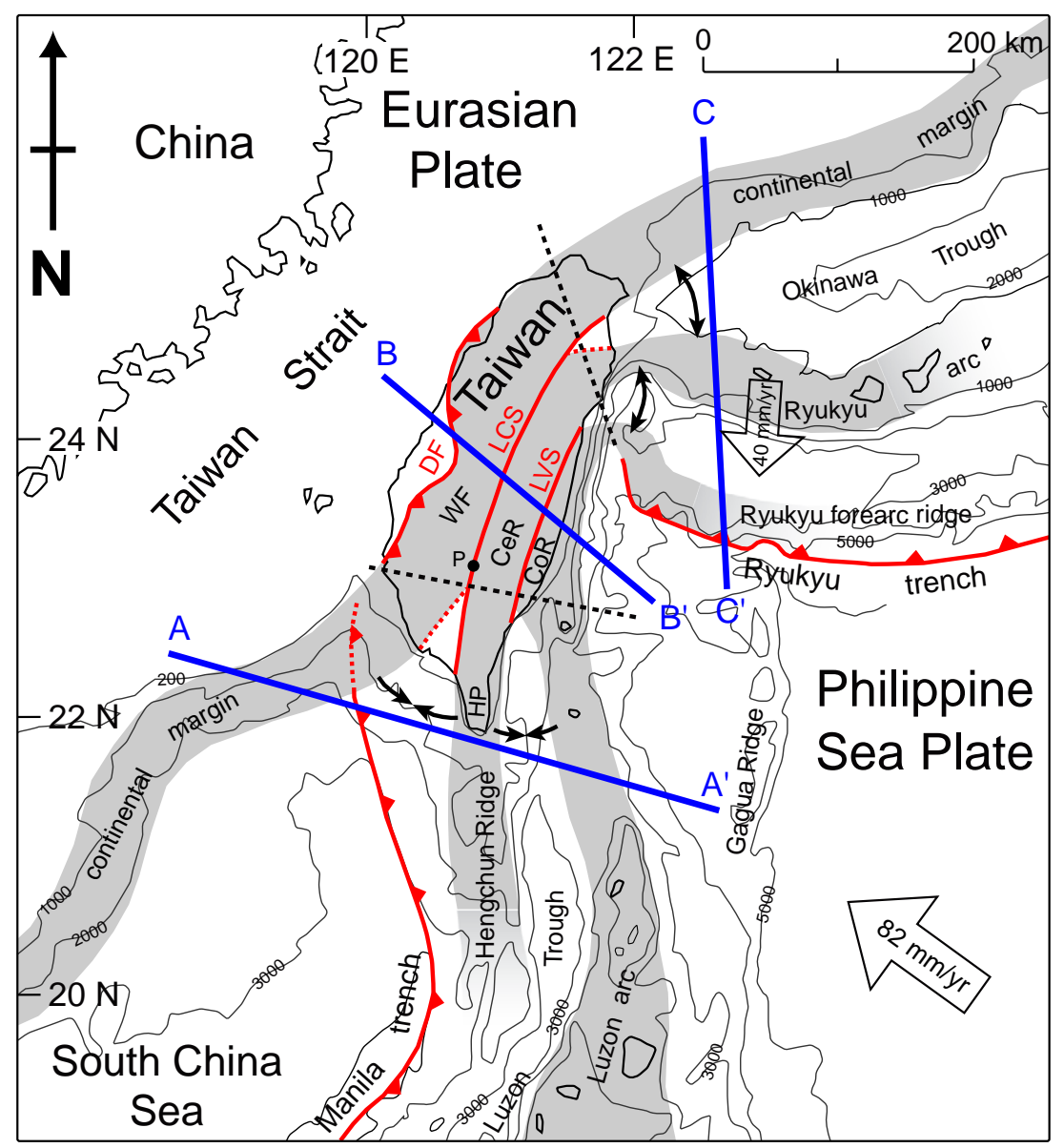

Fig. 2. Taiwan is experiencing a tandem suturing of a volcanic arc and a sliver of continental crust to continental margin. In the south, the Luzon volcanic arc is converging on the Hengchun forearc ridge, which is, in turn, converging on the Chinese continental margin. Suturing of these three elements occurs in the middle of the island. In the north, both sutures are disarticulating, to form both the Okinawa Trough and troughs south of the Ryukyu island arc. Current velocity vector of the Philippine Sea plate is from [5,6]. Current velocity vector of the Ryukyu arc adapted from [30]. Both are relative to the Penghu Islands in the Taiwan Strait. Black dashed lines are the northern and western limits of the Wadati-Benioff zone of the two subducting systems, taken from the seismicity database of the Central Weather Bureau, Taiwan. Bold lines indicate cross-sections of Fig. 3. DF: deformation front; LCS: Lishan-Chaochou suture; LVS: Longitudinal Valley suture; WF: Western Foothills; CeR: Central Range; CoR: Coastal Range; HP: Hengchun Peninsula; P: Outcrops of pillow lava along the western suture.

Hengchun Peninsula and the Hengchun Ridge. Farther north, the similarity of basement rocks beneath the Ryukyu volcanoes to rocks of the Central Range [48] suggests the continuation of the continental sliver beneath the westernmost Ryukyu arc.

This continental sliver may have been split off the eastern margin of the Eurasian continent during the opening of the South China Sea, which occurred about 15 to 32 million years ago (e.g., $[49,50]$ ). Several other continental blocks within the South
China Sea were, in fact, split off the Eurasian margin during this period (e.g., [51,52]). The recovery from wells of pre-Cenozoic rocks similar to the rocks of the Central Range at depths of several thousand meters beneath Taiwan's west coast [53] supports the idea that the Central Range is a sliver derived from the Asian continental margin.

Elimination of the oceanic lithosphere between the Eurasian continental margin, the continental sliver and the Luzon volcanic arc culminates in southern 


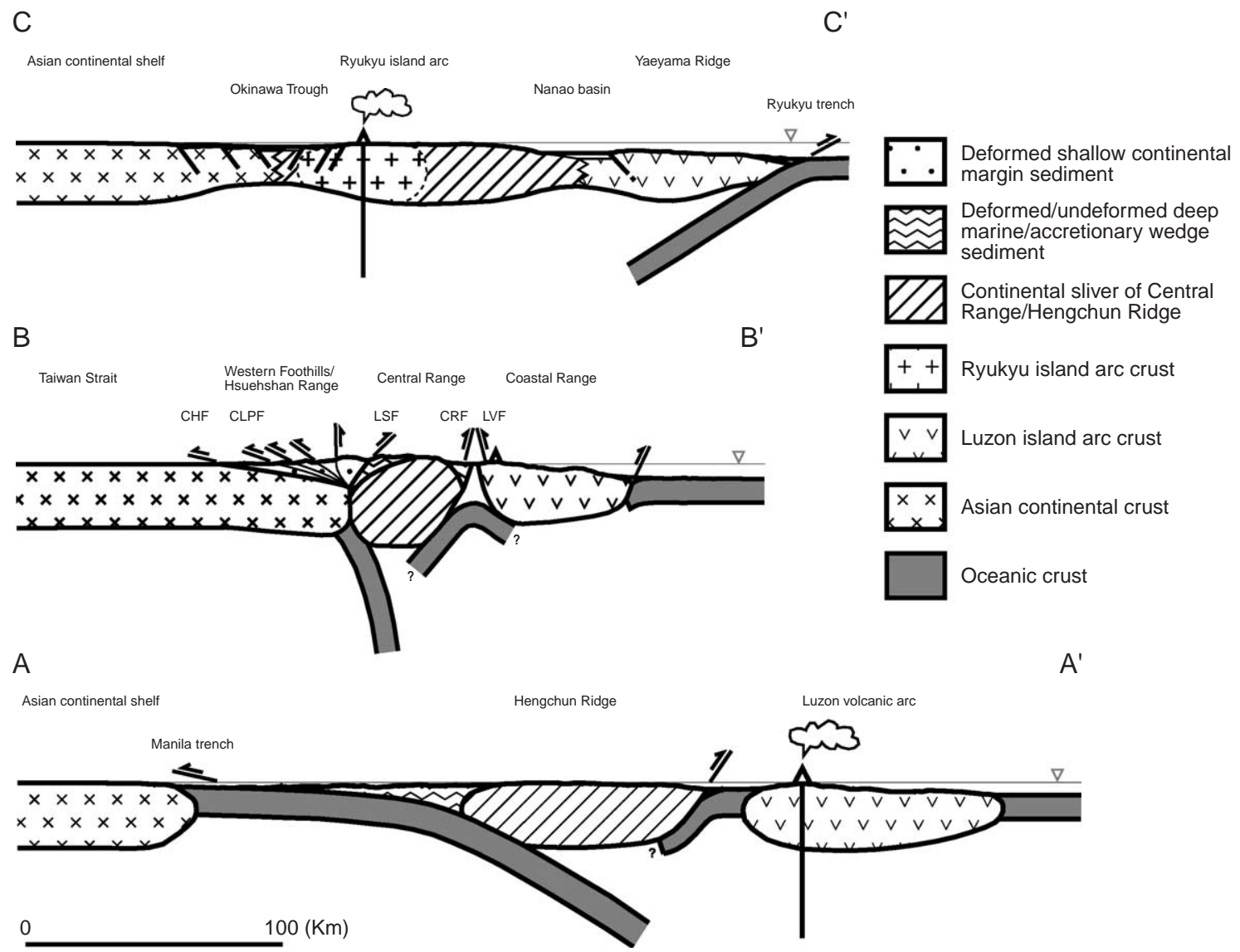

Fig. 3. Three schematic crustal cross-sections across Taiwan illustrate three stages in the process of tandem suturing and disengagement. (A) Section just south of Taiwan shows the final stages of subduction and consumption of oceanic lithosphere between the three buoyant terranes. (B) Section across central Taiwan shows relationship of the three terranes during suturing. (C) Section north and east of Taiwan shows the subduction of the Philippine Sea plate and disengagement of the three terranes across the sutures. CHF: Changhua fault; CLPF: Chelungpu fault; LSF: Lishan fault; CRF: Central Range fault; LVF: Longitudinal Valley fault. No vertical exaggeration.

Taiwan, on either side of the Hengchun Ridge, where oblique convergence between the Luzon volcanic arc and the Eurasian continental margin is occurring at about $80 \mathrm{~mm} / \mathrm{yr}$ [6]. Half of this convergence occurs along the western belt, between the Hengchun Ridge and the continental margin, where oceanic lithosphere of the South China Sea is sliding eastward beneath the Hengchun Ridge continental sliver and the Philippine Sea plate (Fig. 3a). Oceanic lithosphere is being consumed at a similar rate between the Hengchun Ridge and the Luzon volcanic arc. We propose that consumption of this oceanic lithosphere is being facilitated by westward underthrusting of the forearc basin, as suggested by clear bathymetric evidence (e.g., [18,21]). Eastward subduction of forearc lithosphere beneath the Luzon arc has been proposed (e.g., [21,54,55]), but our analysis of bathymetry suggests that this is happening only locally [18].

Consumption of the oceanic fragments west and east of the Hengchun Peninsula is nearing completion at about $23^{\circ} \mathrm{N}$, the northern limit of the WadatiBenioff zone (dashed line in Fig. 2; [56]). The presence of the subducting slab beneath the Pingtung Plain suggests that the rapid subsidence of the plain is related to foundering of subjacent oceanic lithosphere. The termination of the active faults bounding the Pingtung Plain at its northern end also suggests 
that subduction ends and collision begins at that latitude.

Consumption of forearc oceanic crust between the Hengchun Peninsula and the Luzon volcanic arc ends near Taitung, where the thrust faults and folds on the ocean floor disappear (Fig. 1). Ultramafic blocks in the Lichi Formation along the southwestern margin of the Coastal Range (e.g., [33]) are likely the remnants of this forearc oceanic lithosphere (e.g., [20]).

The Lishan fault (LSF), which runs through the center of the island, from $23^{\circ}$ to about $25^{\circ} \mathrm{N}$, represents the western suture (Figs. 2 and 3 ). Although the exact location and the geologic meaning of this fault have been disputed, this structure is extremely obvious topographically and constitutes a major boundary between two very different sedimentary facies of Eocene-Miocene slate on either side of the fault: The slates west of the fault originated in shallow shelf to coastal environments, whereas the slates east of the fault, in the Central Range, formed in a much deeper basin (e.g., [33]). Near the southern end of this structure, Early Miocene(?) pillow lavas that crop out along our proposed western suture ( $\mathrm{P}$ in Figs. 1 and 2; [57]) may well be a remnant of South China Sea oceanic crust.

The accretion of the continental sliver to the continental margin created a myriad of active structures in the fold and thrust belt of western Taiwan. Both the characteristics of the active structures and geodetically determined rates of shortening indicate that the accretion matures northward (e.g., [5]). These thin-skinned structures developed in the deformed sedimentary wedge above and west of the lithospheric suture, and the eastern boundary of the wedge is the Lishan fault (Fig. 3b). This relationship of the thrusts to the Lishan fault would indicate that the western neotectonic belt of Taiwan has both a thick-skinned and a thin-skinned manifestation. The active faults of the Western Foothills are thin-skinned, but they root into a lithospheric suture.

Along the eastern neotectonic belt, suturing of the volcanic arc to the Central Range begins near Taitung, in southeastern Taiwan. There the arc begins its collision with the lithosphere of the Central Range continental sliver, as the intervening oceanic crust disappears beneath the thick accumulation of debris being shed off both terranes. The Longitudinal Valley (Figs. 2 and $3 b$ ) is the subaerial manifestation of the suture. High slip rates on the Longitudinal Valley fault, at the eastern side of the valley, indicate that the final removal of the forearc oceanic lithosphere also involves eastward subduction. The Coastal Range, east of the Longitudinal Valley, consists of a dramatically telescoped assortment of late-Cenozoic arc volcanic and marine sedimentary rocks $[33,58]$, remnants of accreted arc volcanoes and cover sediments of the Luzon Trough (e.g., [20,59]). As along the western neotectonic belt, the degree of development of the structures and lessening of geodetic rates of convergence (e.g., [5]) indicates that suturing matures northward.

Both sutures are disarticulating across northeastern Taiwan. Along the western suture, the continental sliver begins to tear away from the Asian continental margin in the Lanyang Plain, which is bounded by normal faults (Fig. 1). The fact that the apex of the triangle-shaped plain is at the northern end of the Lishan fault indicates clearly that the parting is occurring along the old suture. The plain widens to the east into the westernmost part of the Okinawa Trough (Figs. 2 and 3c).

It is noteworthy that the current arc volcanism in western Ryukyu is localized between the northern part of the Ryukyu arc and the center of the Okinawa Trough (e.g., [60,61]; Fig. 3c). Thus, the Okinawa Trough is not a conventional back-arc basin. Instead, its spreading may be better explained by the postcollisional disengagement of the continental sliver from the Asian continental margin (e.g., [4,61,62]).

In summary, the sliver approaches the continental margin in southern Taiwan, accretes to it in central Taiwan and disengages from the continental margin across the Lanyang Plain in northeastern Taiwan. Normal faulting that created the Taipei Basin is therefore a minor manifestation of the disarticulation of the western suture, off on the western edge of the Western Foothills.

Along the eastern belt, the Coastal Range dives below sea level at the northern end of the Longitudinal Valley to form a bathymetric high between the Ryukyu trench and Hoping basin (Fig. 1). This odd, E-W striking Hsincheng Ridge provides the topographic link between the Coastal Range and the westernmost part of the Yaeyama forearc ridge, immediately north of the Ryukyu trench. We suggest that rocks with affinities to the Coastal Range might 
well be found in the basement of the fold and thrust belt of that part of the Yaeyama forearc ridge. The implication would be that, after suturing to the Central Range lithosphere along the Longitudinal Valley, the lithosphere of the Coastal Range disarticulates from the Central Range along the northeastern coast (Figs. 2 and 3c). Normal faults and complex strike-slip faults surrounding the Hoping basin (Fig. 1) would represent the initiation of this disengagement.

The accretion of pieces of continent and volcanic island arcs onto continental margins is one of the most common phenomena in the geologic record (e.g., $[63,64])$. The disarticulation of lithosphere in areas of former suture zones may also be commonplace in Earth's geologic history (e.g., the Aegean Sea). Taiwan is, however, one of the very few places on Earth that exhibit both phenomena in action in a single orogenic belt; suturing that begins in the south is coming undone in the north and east (Figs. 2 and $3)$. This occurs in tandem, with a separate suture on each side of a narrow sliver of continental material that is caught between the volcanic arc and the continent.

In this example, it is clear that the disengagement of terranes occurs along the not-so-old sutures. This may well reflect a fundamental weakness in the lithospheric sutures. In this case, it appears that all that is needed to induce disengagement of the terranes is the subduction of the Philippine Sea plate along the Ryukyu subduction zone to a position below the upper crust. Once this buttress is removed, the two sutures disengage.

\section{Implications for future earthquake sources}

The tandem-suture model of the Taiwan orogen raises interesting questions with respect to the evaluation of seismic hazard in Taiwan. It is plausible that a large earthquake could be generated by slip on the subduction interface beneath Kaohsiung, Tainan, and the Pingtung Plain. In addition, a myriad of smaller potentially seismic sources lie within the hanging-wall block of the subduction interface there. Only the question is: Which of these are locked and potentially seismic, and which are slipping aseismically?
Large thrust faults in the submarine realm south of Taitung may also generate large subduction-like earthquakes. High rates of suturing along the southern Longitudinal Valley should mean that large earthquakes are more common there than in the northern Longitudinal Valley, as has been the case during the century or so of recorded history.

One can reasonably expect the blind thrust faults of the western neotectonic belt (in the Chiayi and Miaoli Domains) to generate earthquakes at least as large as that generated in 1999 by the intervening Chelungpu thrust. The normal fault on the western side of the Taipei Basin half-graben should generate earthquakes less frequently than normal faults near the Lanyang Plain, because strain rates are so much lower across the Taipei Basin. One can expect the western margin of the Ryukyu subduction zone to generate a bewildering variety of large earthquakes, given the abundance of right-lateral tear faults and normal faults there.

Finally, rapid uplift of the Central Range may not imply loading of seismic sources within the Central Range lithosphere. Instead, pervasive ductile crustal thickening may produce the rapid uplift.

\section{Concluding remarks}

The construction of this tandem-suture model of the Taiwan orogen was made possible by our comprehensive mapping of the neotectonic elements of Taiwan. Our descriptions of active structures, in combination with previously published structural, stratigraphic and geophysical information necessitated a new tectonic framework for the orogen. This new tectonic framework involves three lithospheric elements, two continental and one island-arc, which first suture and then disengage.

The model could be tested with a number of new observations. For example, is the unexposed basement of the Hengchun Ridge actually similar to the metamorphic core of the Central Range; are there island-arc rocks beneath the sediments of the westernmost Yaeyama forearc ridge; and is there still oceanic lithosphere beneath the thick clastic fill of the Longitudinal Valley? Some of these questions can be answered by well-designed ocean-drilling projects. More investigations should be able to verify the cross- 
sections we proposed in Fig. 3. We hope, in fact, that the tandem suturing and disarticulation model will be subjected to such tests.

\section{Acknowledgments}

We are grateful for valuable discussions with J.-P. Avouac, O. Beyssac, W.-C. Chi, C.-Y. Lu, Y. Ota, C. Rubin, J. Saleeby, L.S. Teng, and B. Wernicke. Also, we have benefited from stimulating discussions with students of two field classes in Taiwan and a neotectonic seminar at National Taiwan University. We appreciate valuable comments and suggestions of three anonymous reviewers of the manuscript and a previous version. Our neotectonic mapping would have been impossible had C.-T. Lee and C.-S. Liu not made high-quality digital topography and bathymetry available to us. Our mapping was facilitated by J. Giberson, manager of the Caltech's GIS laboratory. Our project in Taiwan was initially supported by private funds of Caltech's Division of Geological and Planetary Sciences and later by NSF grant EAR0208505. This research was also supported in part by the Gordon and Betty Moore Foundation. This is Caltech Tectonic Observatory Contribution \#1.

\section{References}

[1] C.S. Ho, A synthesis of the geologic evolution of Taiwan, Tectonophysics 125 (1986) 1-16.

[2] L.S. Teng, Stratigraphic records of the late Cenozoic Penglai orogeny of Taiwan, Acta Geol. Taiwan. 25 (1987) 205-224.

[3] L.S. Teng, Late Cenozoic arc-continent collision in Taiwan, Tectonophysics 183 (1990) 57-76.

[4] L.S. Teng, Extensional collapse of the northern Taiwan mountain belt, Geology 24 (1996) 949-952.

[5] S.-B. Yu, H.-Y. Chen, L.-C. Kuo, Velocity field of GPS stations in the Taiwan area, Tectonophysics 274 (1997) 41-59.

[6] S.-B. Yu, L.-C. Kuo, R.S. Punongbayan, E.G. Ramos, GPS observation of crustal deformation in the Taiwan-Luzon region, Geophys. Res. Lett. 26 (1999) 923-926.

[7] N. Hovius, C.P. Stark, H.-T. Chu, J.-C. Lin, Supply and removal of sediment in a landslide-dominated mountain belt: Central Range, Taiwan, J. Geol. 108 (2000) 73-89.

[8] M.G. Bonilla, A Review of Recently Active Faults in Taiwan, USGS Open-File Rep. 75-41, U.S. Geological Survey, Menlo Park, CA, 1975, 58 pp.

[9] M.G. Bonilla, Summary of quaternary faulting and elevation changes in Taiwan, Mem. Geol. Soc. China 2 (1977) 43-55.
[10] M.-T. Hsu, Earthquake Catalogues in Taiwan (from 1644 to 1979), National Taiwan University, Taipei, 1980, 77 pp. (in Chinese).

[11] S.N. Cheng, Y.T. Yeh, Catalog of the Earthquakes in Taiwan from 1604 to 1988, Institute of Earth Sciences, Academia Sinica, Taipei, 1989, 255 pp. (in Chinese).

[12] K.-F. Ma, T.-R.A. Song, S.-J. Lee, H.-I. Wu, Spatial slip distribution of the September 20, 1999, Chi-Chi, Taiwan, earthquake (Mw7.6) - inverted from teleseismic data, Geophys. Res. Lett. 27 (2000) 3417-3420.

[13] K.-F. Ma, J. Mori, S.-J. Lee, S.B. Yu, Spatial and temporal distribution of slip for the 1999 Chi-Chi, Taiwan, earthquake, Bull. Seismol. Soc. Am. 91 (2001) 1069-1087.

[14] Y.-G. Chen, W.-S. Chen, J.-C. Lee, Y.-H. Lee, C.-T. Lee, H.-C. Chang, C.-H. Lo, Surface rupture of 1999 Chi-Chi earthquake yields insights on active tectonics of central Taiwan, Bull. Seismol. Soc. Am. 91 (2001) 977-985.

[15] C. Ji, D.V. Helmberger, T.-R.A. Song, K.-F. Ma, D.J. Wald, Slip distribution and tectonic implication of the 1999 ChiChi, Taiwan, earthquake, Geophys. Res. Lett. 28 (2001) 4379-4382.

[16] K.M. Johnson, Y.-J. Hsu, P. Segall, S.-B. Yu, Fault geometry and slip distribution of the 1999 Chi-Chi, Taiwan earthquake imaged from inversion of GPS data, Geophys. Res. Lett. 28 (2001) 2285-2288.

[17] K.I. Kelson, K.-H. Kang, W.D. Page, C.-T. Lee, L.S. Cluff, Representative styles of deformation along the Chelungpu fault from the 1999 Chi-Chi (Taiwan) earthquake: geomorphic characteristics and responses of man-made structures, Bull. Seismol. Soc. Am. 91 (2001) 930-952.

[18] J.B.H. Shyu, K. Sieh, Y.-G. Chen, C.-S. Liu, The neotectonic architecture of Taiwan and its implications for future large earthquakes, J. Geophys. Res. (in press).

[19] N. Lundberg, D.L. Reed, C.-S. Liu, J. Lieske Jr., Forearcbasin closure and arc accretion in the submarine suture zone south of Taiwan, Tectonophysics 274 (1997) 5-23.

[20] C.P. Chang, J. Angelier, C.Y. Huang, C.S. Liu, Structural evolution and significance of a mélange in a collision belt: the Lichi Mélange and the Taiwan arc-continent collision, Geol. Mag. 138 (2001) 633-651.

[21] J. Malavieille, S.E. Lallemand, S. Dominguez, A. Deschamps, C.-Y. Lu, C.-S. Liu, P. Schnürle, the ACT scientific crew, Arccontinent collision in Taiwan: new marine observations and tectonic evolution, Spec. Pap.-Geol. Soc. Am. 358 (2002) $187-211$.

[22] O. Lacombe, F. Mouthereau, J. Angelier, B. Deffontaines, Structural, geodetic and seismological evidence for tectonic escape in SW Taiwan, Tectonophysics 333 (2001) $323-345$.

[23] J.B.H. Shyu, L.-H. Chung, Y.-G. Chen, J.-C. Lee, K. Sieh, Reevaluation of the surface ruptures of the November 1951 earthquake series in eastern Taiwan, and its neotectonic implications, J. Asian Earth Sci. (submitted for publication).

[24] H.-H. Chen, R.-J. Rau, Earthquake locations and style of faulting in an active arc-continent plate boundary: the Chihshang fault of eastern Taiwan, Eos Trans. AGU, Fall Meet. Suppl. 83 (47) (2002) F1281. 
[25] J. Suppe, The active Taiwan mountain belt, in: J.P. Schaer, J. Rodgers (Eds.), Anatomy of Mountain Chains, Princeton University Press, Princeton, NJ, 1987, pp. 277-293.

[26] J. Suppe, J. Namson, Fault-bend origin of frontal folds of the western Taiwan fold-and-thrust belt, Pet. Geol. Taiwan 16 (1979) 1-18.

[27] J. Suppe, Décollement folding in southwestern Taiwan, Pet. Geol. Taiwan 13 (1976) 25-35.

[28] L.S. Teng, C.T. Lee, C.-H. Peng, W.-F. Chen, C.-J. Chu, Origin and geological evolution of the Taipei Basin, northern Taiwan, West. Pac. Earth Sci. 1 (2001) 115-142.

[29] Y.-T. Shieh, The paleogeography of the ancient Taipei lakebed in the K'anghsi Period, J. Geogr. Sci. 27 (2000) 85-95 (in Chinese with English abstract).

[30] S. Lallemand, C.-S. Liu, Geodynamic implications of presentday kinematics in the southern Ryukyus, J. Geol. Soc. China 41 (1998) 551-564.

[31] E. Barrier, J. Angelier, Active collision in eastern Taiwan: the Coastal Range, Mem. Geol. Soc. China 7 (1986) 135-159.

[32] C.-Y. Huang, W.-Y. Wu, C.-P. Chang, S. Tsao, P.B. Yuan, C.W. Lin, K.-Y. Xia, Tectonic evolution of accretionary prism in the arc-continent collision terrane of Taiwan, Tectonophysics 281 (1997) 31-51.

[33] C.S. Ho, An introduction to the geology of Taiwan, explanatory text of the geologic map of Taiwan, Central Geological Survey, 2nd ed., Ministry of Economic Affairs, Taipei, 1988, 192 pp.

[34] S.-K. Hsu, J.-C. Sibuet, Is Taiwan the result of arc-continent or arc-arc collision?, Earth Planet. Sci. Lett. 136 (1995) 315-324.

[35] J.-C. Sibuet, S.-K. Hsu, Geodynamics of the Taiwan arc-arc collision, Tectonophysics 274 (1997) 221-251.

[36] F.T. Wu, R.-J. Rau, D. Salzberg, Taiwan orogeny: thinskinned or lithospheric collision?, Tectonophysics 274 (1997) 191-220.

[37] A.I. Chemenda, R.-K. Yang, J.-F. Stephan, E.A. Konstantinovskaya, G.M. Ivanov, New results from physical modelling of arc-continent collision in Taiwan: evolutionary model, Tectonophysics 333 (2001) 159-178.

[38] C.-Y. Lu, K.J. Hsü, Tectonic evolution of the Taiwan mountain belt, Pet. Geol. Taiwan 27 (1992) 21-46.

[39] L.P. Tan, Pleistocene eastward bending of the Taiwan arc, Mem. Geol. Soc. China 2 (1977) 77-83.

[40] J. Suppe, Kinematics of arc-continent collision, flipping of subduction, and back-arc spreading near Taiwan, Mem. Geol. Soc. China 6 (1984) 21-33.

[41] W.-S. Chen, Y.-M. Cheng, C.-Y. Huang, Geology of the Hengchun Peninsula, southern Taiwan, Ti-Chih 6 (2) (1985) 47-74 (in Chinese with English abstract).

[42] Q.-C. Sung, Y. Wang, Petrofacies of Miocene sediments in the Hengchun Peninsula and its tectonic implication, Proc. Geol. Soc. China 28 (1985) 23-44.

[43] Q. Sung, Y. Wang, Sedimentary environments of the Miocene sediments in the Hengchun Peninsula and their tectonic implication, Mem. Geol. Soc. China 7 (1986) 325-340.

[44] Y.-G. Chen, T.-K. Liu, Holocene radiocarbon dates in Hengchun Peninsula and their neotectonic implications, J. Geol. Soc. China 36 (1993) 457-479.
[45] Y.-G. Chen, T.-K. Liu, Holocene uplift and subsidence along an active tectonic margin southwestern Taiwan, Quat. Sci. Rev. 19 (2000) 923-930.

[46] W.-C. Chi, D.L. Reed, C.-S. Liu, N. Lundberg, Distribution of the bottom-simulating reflector in the offshore Taiwan collision zone, Terr. Atmos. Oceanic Sci. 9 (1998) 779-794.

[47] Y. Nakamura, K. McIntosh, A.T. Chen, Preliminary results of a large offset seismic survey west of Hengchun Peninsula, southern Taiwan, Terr. Atmos. Oceanic Sci. 9 (1998) 395-408.

[48] K. Kizaki, Geology and tectonic framework of the Ryukyu Islands, Mem. Geol. Soc. China 7 (1986) 1-14.

[49] A. Briais, P. Patriat, P. Tapponnier, Updated interpretation of magnetic anomalies and seafloor spreading stages in the South China Sea: implications for the Tertiary tectonics of Southeast Asia, J. Geophys. Res. 98 (1993) 6299-6328.

[50] T.-Y. Lee, L.A. Lawver, Cenozoic plate reconstruction of Southeast Asia, Tectonophysics 251 (1995) 85-138.

[51] T.-Y. Lee, L.A. Lawver, Cenozoic plate reconstruction of the South China Sea region, Tectonophysics 235 (1994) $149-180$.

[52] A.T. Lin, A.B. Watts, S.P. Hesselbo, Cenozoic stratigraphy and subsidence history of the South China Sea margin in the Taiwan region, Basin Res. 15 (2003) 453-478.

[53] B.-M. Jahn, W.-R. Chi, T.-F. Yui, A late Permian formation of Taiwan (marbles from Chia-Li Well No.1): $\mathrm{Pb}-\mathrm{Pb}$ isochron and $\mathrm{Sr}$ isotopic evidence, and its regional geological significance, J. Geol. Soc. China 35 (1992) 193-218.

[54] A.I. Chemenda, R.K. Yang, C.-H. Hsieh, A.L. Groholsky, Evolutionary model for the Taiwan collision based on physical modelling, Tectonophysics 274 (1997) 253-274.

[55] J.-C. Tang, A.I. Chemenda, J. Chéry, S. Lallemand, R. Hassani, Compressional subduction regime and initial arccontinent collision: numerical modeling, Spec. Pap.-Geol. Soc. Am. 358 (2002) 177-186.

[56] H. Kao, G.-C. Huang, C.-S. Liu, Transition from oblique subduction to collision in the northern Luzon arc-Taiwan region: constraints from bathymetry and seismic observations, J. Geophys. Res. 105 (2000) 3059-3079.

[57] C.-S. Kuo, Geochemistry and Isotopic Analysis of Spilite in the Paolai Area, MS Thesis, National Taiwan University, Taipei, 1984, 96 pp. (in Chinese).

[58] W.-S. Chen, Tectonic Evolution of Sedimentary Basins in Coastal Range, Taiwan, PhD thesis, National Taiwan University, Taipei, 1988, 304 pp. (in Chinese).

[59] C.-Y. Huang, C.-T. Shyu, S.B. Lin, T.-Q. Lee, D.D. Sheu, Marine geology in the arc-continent collision zone off southeastern Taiwan: implications for Late Neogene evolution of the Coastal Range, Mar. Geol. 107 (1992) 183-212.

[60] J.-C. Sibuet, B. Deffontaines, S.-K. Hsu, N. Thareau, J.-P. Le Formal, C.-S. Liu, ACT party, Okinawa trough backarc basin: early tectonic and magmatic evolution, J. Geophys. Res. 103 (1998) 30245-30267.

[61] S.-L. Chung, S.-L. Wang, R. Shinjo, C.-S. Lee, C.-H. Chen, Initiation of arc magmatism in an embryonic continental rifting zone of the southernmost part of Okinawa Trough, Terra Nova 12 (2000) 225-230. 
[62] K.-L. Wang, S.-L. Chung, C.-H. Chen, R. Shinjo, T.F. Yang, C.-H. Chen, Post-collisional magmatism around northern Taiwan and its relation with opening of the Okinawa Trough, Tectonophysics 308 (1999) 363-376.

[63] J.B. Saleeby, Accretionary tectonics of the North American Cordillera, Annu. Rev. Earth Planet. Sci. 15 (1983) 45-73.
[64] A.M.C. Şengör, B.A. Natal'in, Paleotectonics of Asia: fragments of a synthesis, in: A. Yin, M. Harrison (Eds.), The Tectonic Evolution of Asia, Cambridge University Press, Cambridge, 1996, pp. 486-640. 